「アパレル」特集

\title{
21世紀へのファッションテクノロジー
}

清 水 義 雄

\section{1. 宇宙船地球号一多様な他者との豊かな共生一}

20世紀の終わりを迎えて, 今世界が激しく変わりつつ ある。ヨーロッパ経済共同体やアメリカ・カナダの経済 協力体制, ソ連の解体などの様に, 分離と融合が急激に 生じて，歪を含んだまま固定されていた世界が，より自 然な形を求めて動きだした。

このような変動は, 科学技術的な背景から見ると, 物 質・エネルギーの近代科学技術から情報科学技術への移 り変わりと密接な関係にある。即ち, 近代科学技術は,

物質の生産性を向上させ，大量生産により近代産業社会 を支え，さらにハイテクと呼ばれる様々な革新技術を産 みだした。このハイテクの中心をなすものは，計算機を 始めとする情報機器で，この進歩が近代工業化社会に対 する物の見方・考え方を変えようとしている。例えば通 信衛星の発達により, 地球上の様々な出来事は, どこの 国の人でも同時に同じ事件を見たり聞いたりでき，情報 に对する多様性と同時性の認識手段を手にすることがで きるようになった。この結果, 地球的規模の環境問題 も，すみずみまで目が届くようになり，地球はもう無限 の大きさの大地や海や空からできていないと言うこと を，日常人々は意識し始めている。ゴミや污水を垂れ流 せば自分の飲み水が污れ，ばい煙やフロン，二酸化炭素 などを安易に気中に捨てれば酸性雨, オゾン層破壊, 温 暖化となって我が身に降りかかることを知れば，今まで の無限に大きい地球と言うイメージを変えなければなら なくなっている。

以上のことを総合すれば, 情報科学技術時代に生きる とは, 多種多様な人々が, 互いにコミュニケーションを 交わし合いながら，小さな宇宙船地球号に乗ることであ ると気づく（図1)。

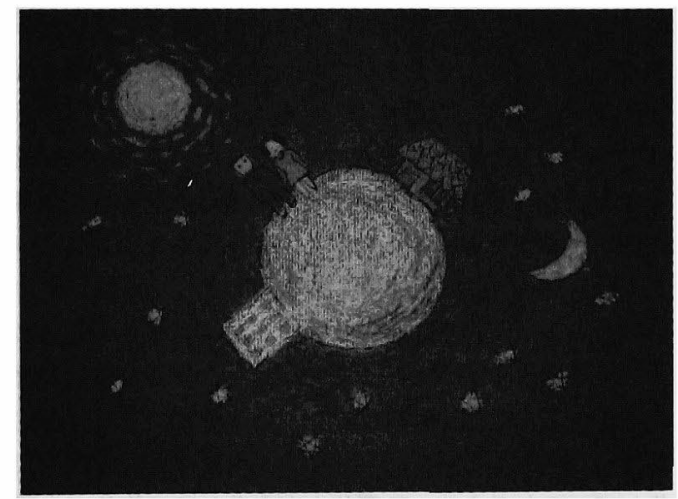

図 1 宇宙船地球号

一方, 現在の激動は, 近代科学技術と言う物質科学を 背景にした, 社会主義, 共産主義, 資本主義などと言っ たイデオロギー的な社会観が崩壊して，より自由で一人 一人の存在を大切にする民主主義の実践に向かっての移 行過程と見ることもできる。民主主義の実践とは，一人 一人がより充実した自己を実現し, 物質的豊かさから精 神的豊かさへ転換した人間的に豊かな生活をすることで ある。しかし，もはや自分一人たけの豊かさを求めてい たのでは豊かさの実現は困難であり、「地球全体の環境 の保全・保護」が必要であり,「他者も豊かに生活して いること」が満たされなければならず,「多様な価值観 を持った他者との共生」を人々は願い始めた。

この様な考え方は, 宇宙船地球号と言う小さな乗合バ スに相乗りして行くしかないという現実がもたらした結 果であり,この認識の上にこそ, 今まで明確なイメージ を持ちにくかった「民主主義」に、「多様な他者との豊 かな共生」と言う具体的な意味が与えられる。

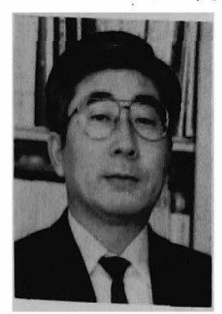

Fashion Technology in the 21th Century

筆者紹介 YOSHIO SHIMIZU

Faculty of Textile Science and Technology, Shinshu University

信州大学織維学部, 助教授, 工学博士

筆者は樴維製品工学, 衣服工学を専門とされ, 現在「対話型デザインの研究」等を通じユーザーの個性

にあった衣服作り(ファッションテクノロジー) に従事されている。趣味は山歩き。

本稿では上記研究の意味, 方法と成果, 今後の展望について解説していたたいた。 


\section{2. ファッションテクノロジーの役割}

以上のように，多様な洒値観を持った人々との共生を 宇宙船地球号の中で寒現していくのが，21世紀の課題で ある。では、新しい世紀に、ファッションテクノロジー はどの様な意味と役割を果たすのかを考えてみたい。

\section{1 変化し続けて存在する形・ファッション}

ファッションという言葉は，辞書によると，服装や風 俗並びに言語の流行, 様式, 方法, 形という意味の他に ライフスタイルなどもあり，使う人々によって多様に用 いられているが,ここでは、「形」をファッションの意 味とする。形と言う䓂葉に，目や手などの感覚器官を通 して認識される形の他に，話し方，感じ方，考え方，生 き方など存在するすべてを形という言葉で代表させる。

また、形或いは存在するものすべては，一般的には， 「いつも一定不変な形を保っているが故に存在する」と 言う考え力がなされるが、これを、「いつも变化し続け ることによって存在し続ける」と考える。つまり，変化 していないようにみえるしっかりした形はど，激しく変 化していると考える。物理的な存在としての物体（衣服 や石仏など）はてれを侢成している糨子間の激しく変化 する振動現象の連続として考えられるが，美しいものを 見たときの感情や，妻に対する愛情や人生に対する考之 万などの脳の中に生じる様々な感情や考え方も，その形 が強い程, 美しい程, 强い意志とエネルギーで思い続け ることができ，変化しながら存在し続けることができる と考える。このためみない変化の連続として形（考えや 感情など）を維持し続ける意志と緊張感が，䑈を活性化 して，快適を感じ，光実感のある人生を可能としてい 万。

\section{2 かっこよく生きる技術}

人間はたえす欲求をもって生をる動物である。様々な 欲求が人の心の中に存在するMaslow ${ }^{13}$ " McGregor ${ }^{21}$ は，人間の欲求を低次加高次の5段階に分けて説明し ている。低次の欲求から順に挙壮ていく之, (1)生物的生 存欲求, (2)安全・保全欲求, (3)社会的㷌㟲の钦求, (4)自 我の欲求, (5)自己実現の欲求となる。物質的に豊かな現 在では(1), (2), (3)の欲求はほとんど满たされており，(4) 自我の欲求や(5)自己㿤現の欲求に重点がおかれる。特 に，精神的に自己を高め充実した人生を送りたいと言う 自己実現の欲求が今後の中心課題となるだろう。自己実 現の欲求を満たすとは，人それぞれの感性に従ってく心 地よさ」を満たしてくれるモノや精神的な形を求めるこ とである。「心地よさ」とは，「脳が快感を感じる」こと であり，前節で述べた，強くて，美しい形（感情や考え 方）をたゆみない变化の連続として維持し続けることで
ある。

つまり、ファッションテクノロジーとは, Maslowや McGregor の言う「自己実現」の技術であり，「よい 形，美しい形によって䒧実した人生を送る。為の技術の ことであり，「かっこよい」生き方をするための技術と 㸒うことになる。

\section{21世紀のファッションテクノロジー}

Maslow や McGregor の言う最終的な価値レヘルにあ る自己奏現の欲求は，精神的に充足された「快適なっ状 態を脳の中に作り出すことであると考え，これを実現す る技術のことを前節でファッションテクノロジーと定库 した。脳の快感を得るためには，薬に賴るなど種々の方 法がある。しかし大切なことは, 宇宙船地球号の他の人 との共生をしながら自分の形を作り、結果として心地よ さを得ることが条件である。個人の快感が閉鎖された固 人の中だけで生じるようなものなら「多様な他者との豊 かな共生」はできない。

また，他者とのやり取りには被服などの物質の介在が 必要である。それによって得られる快感は，精神的な現 象であるが，これを得るには様々な道具立てが必要であ る。

カーライルは，衣装梠学 ${ }^{3}$ で「間の現世的な関心が きっちりボタンで留められ，服に支えられて立ってい る」と言っているが，服を見ただけで年龄、国籍、財 力, 社会的地位ばかりが, 倜人的な微妙な個性や思想ま で見抜くことができる。このように，我々が利用する被 服などのモノは，それを用いる人を代表し，人と人とを 関係づけるインターフェースであり，自己実現を達成す るためになくてはならないモノである。

\section{1 消䨗される物作りから，用いられるモノ作りに}

しかし，現在巷にあふれている物は，それを利用する 特定の人を意識して作られることはなく大量に生座され て，大量に消費されることを前提としている。例えば， 下着一つ取り上げてみても自分の体にビッタリの製品を 探し出すことは非常に難しい。

製品を享受するユーザーの立場に立てば，ユーザーに ピッタリのモノが日常のストアーで注文できるシステム が欲しい。しかも，利便性や機能性もさることながらー 人一人の知性や感性に剂応した物語性のある本物のモ） が欲しい。バブル経済がはじけた合，堅実なユーザー は，本当に必要なよいモノを求めている。本物に村する 市場は先分に成熟している。後は，どの㮞にしてこの市 場要求に応えるモノ作りのシステムを作るかでる。 


\section{2 ユーザーモデルを持つ生産システム}

製品が生産される時の,メーカーとユーザーとの関係 は様々であるが，大きく分けてみれば次の3つになる。 (1)一つは, 性能・機能・形態などが固定しており, 特定 のユーザーを持たず大量生産を基本とするもので，ユー ザーモデルを必要としないもの。(2)二つは, 不特定多数 の消費者をいくつかのグループに分け，グループごとに 一定な性能・機能・形態などを特たせ，場合によっては 消費者の要求を限られた範囲で満たした製品で, 複数の ユーザーモデルを想定しているもの。(3)三つは, 特定の ユーザーのためにのみ作られる一品製品で，特定のユー ザーモデルを持つもの。

高度に発達した技術社会の今, 我々が使うどの様なモ ノでも我々の好みに合わせて作ってもらえるようなシス テムがあってもよいと思う。しかし現状は，手作りを主 とする場合を除いて，ほとんどの製品が，(1)関係によ って生産されており，ユーザーの好みに合わせて製品を 供給できるシステムはない。毎日使う多くのモノが,一 人一人のユーザーのために生産されて，ユーザーが豊か な気持ちで日々を送ることができること、これが次の時 代には，必要である。そのためには，メーカーは，ユー ザー一人一人の感性, 好みなどの特徎や製品の利用目的 などを把握すること（ユーザーモデルを持つこと）が大 切である。

\section{3 ユーザーモデル}

被服のようなモノは, 様々な製品の中でもユーザーの 個性を最もよく反映するモノである。従って，ユーザー モデルを持った個人対応のモノ作りの例として，被服作 りは，最適である。21世紀のファッションテクノロジー は，被服作りに凝縮できると考えられる。

さて，ユーザーモデルの定義をしておく，ユーザー (着装者)を，ありのまま全部理解することはできない から, 対象となるユーザーを代表すると考えられるいく つかの事柄を取り上げ，抽象化，データ化して記述した

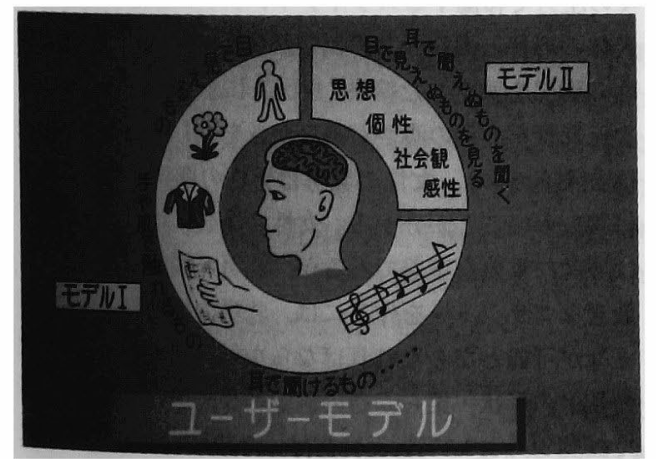

困2 ユーザーモデル
ものがユーザーモデルである。従って，モデル化の方法 によって様々なモデルが生ずる。

図 2 に示すようにユーザーモデルは，例えば物理的な ものとメンタルなものがある。物理的なモデルとは, 着 装者の人体や作ろうとする被服の物理的特性（形状, 機 能, 動的な特性) などであり,メンタルモデルとは，着 装者の感性（被服の美しさや着心地など）や知性（物の 考え方）などの他に社会的状態（職業や地位など）も含 める場合もある。

各事柄をどの様にモデル化するかは，重要な問題であ る。人体や被服の形状などは，表面各点の三次元数値デ ータ（一般的には，圧縮されたもの）がモデルであり, 被服の温熱特性は clo 值などを採用すればよい。被服デ ザインの場合には，パターンデータや画像データの集合 がモデルである。以上のように一般に物理モデルは, 数 值の集まりとして表現されるが, メンタルモデルは, 数 值で表すことができるものとできないものがある。例え ば官能検査によって統計的に処理された場合には数值的 なモデルとして表現できるが，一般的にはメンタルモデ ルは，明文化モデルである。また，後述のようなニュー ラルネットやファジイ的な手法で複雑な人間の感性モデ ルを表現することもできる。

\section{4. ファッションテクノロジーの要素技術}

以上のような考え方に立って，多くの人が気軽に自分 の好みにあった一品モノの高品位被服を生産するコンピ ュータ支援オーダーメイドシステム（エレガンス・オー

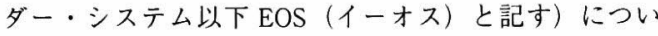
て考えてみよう。図 3 は, 現在我々が開発中の EOS の 概略図である。EOS は，着装者自身が設計に参加して 自分好みの被服ができるよう，対話型（ユーザーとシス テムとが会話をしながら）システムとなっている。この 図は, 次世代のファッションテクノロジーの種々の要素 技術を含んでいる。

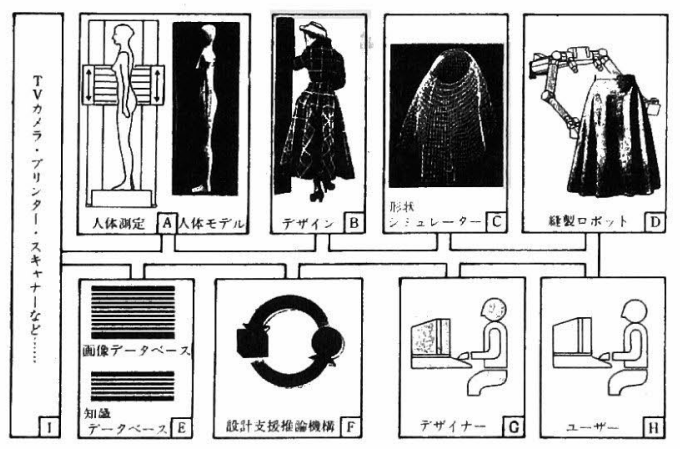

図３エレガンスオーダーシステム 


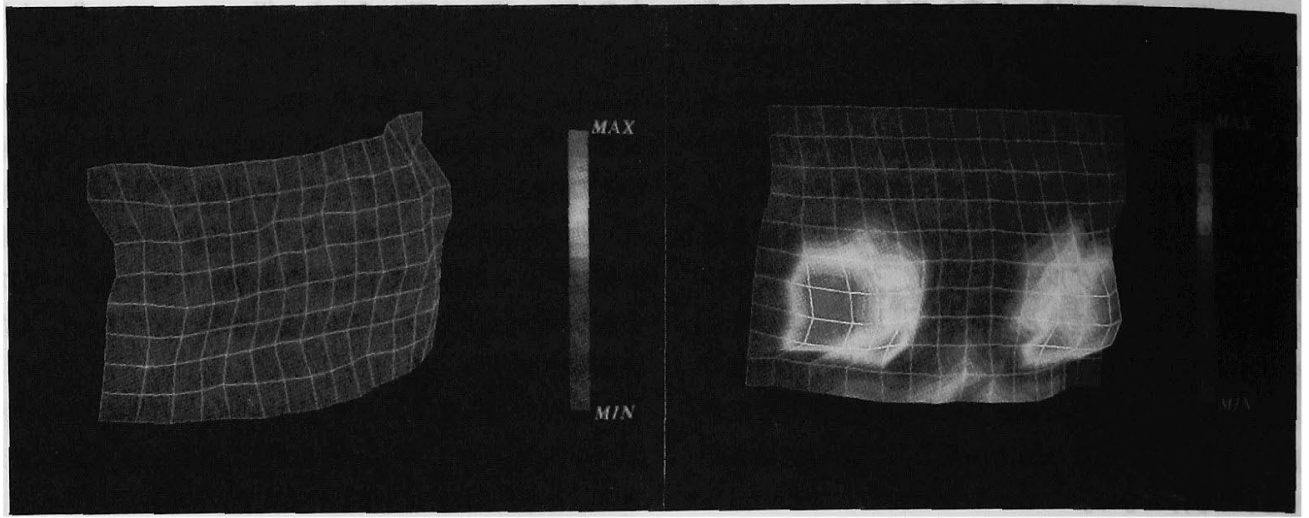

男性

女性

図4胸部の形状と柔らかさ

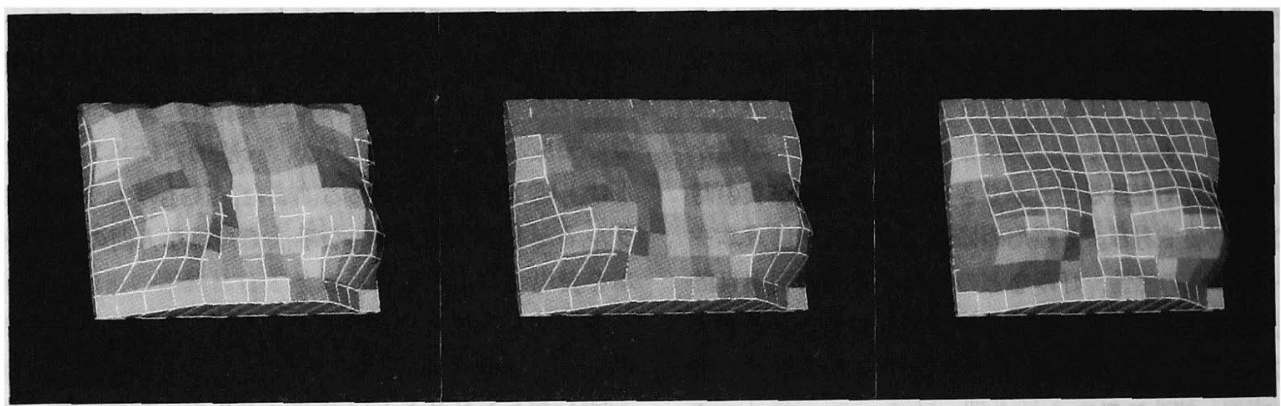

(a)乳房を持ち上げ

(b)下がり始め

(c)下に垂れる

図 5 女性の胸の振動シミュレーション

まず，体に合った被服作りには，着装者の体の特徵を 知ることが大切である。人体測定装置によって体の形状 や柔らかさなどの特性を測り，ユーザーの人体モデルを 作る(A)。ユーザーと対話する事によって, 着装目的や被 服の好みなどを知りメンタルユーザーモデルを作る。こ れらの人体モデルとメンタルモデルとを基に画像データ ベース（様々な被服のパターンや図案が格納）や知識デ ータベース（材料の知識など）(E)を活用して, デザイン を行う(B)。着装状態の形状を求めるには, 形状シミュレ ータを用いる(C)。以上のような設計データは，縫製ロボ ットに送られて型紙生成, 生地裁断, 三次元立体縫制の 工程を経て被服に仕立てあげられる(D)。設計に当たって は専門的なコンピュータ等の知識を必要とせず，日常の 言語によって被服の形や色採を決定できるようなユーザ ーインターフェイスが不可欠である(H)。ユーザーが行っ た被服デザインを, 最終的に専門のデザイナーが確認や アドバイスを行うようにする。これによって，信頼感の ある被服を供給することができる(G)。尚, 設計推論機構

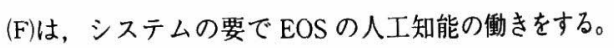
以上の要素技術の中から現在開発中のいくつかの例に ついて簡単に紹介したい。

\section{1 人体の形状と特徵の把握}

人体の形状や柔らかさ等は人によって著しく異なって いるが,この違いを測定し被服の設計に利用したい。種 々の圧力で移働するスライディングゲージを多数備えた 人体の形状と柔らかさの測定装置 ${ }^{4}$ を用いて，女性と男 性の胸部を測定した給果 ${ }^{5)}$ を図 4 に示すが，折れ線が三 次元形状を，色の濃さが柔らかさを表している(白い所 ほど柔らかい)。女性の乳房は男性の胸に比較して非常 に柔らかいことが分かる。女性の場合には、ブラジャー は非常に重要な下着であるが, 乳房が振動しないように 最適なブラジャーを作るには，乳房の振動シュミレーシ ヨンが可能とならなければならない。図4に示した女珄 の乳房の形状・柔らかさの測定結果を用いてモート解析

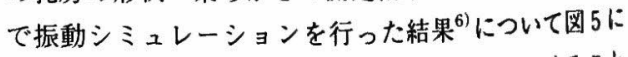
示す。上方に持ち上げられていた乳房が下ってくること 

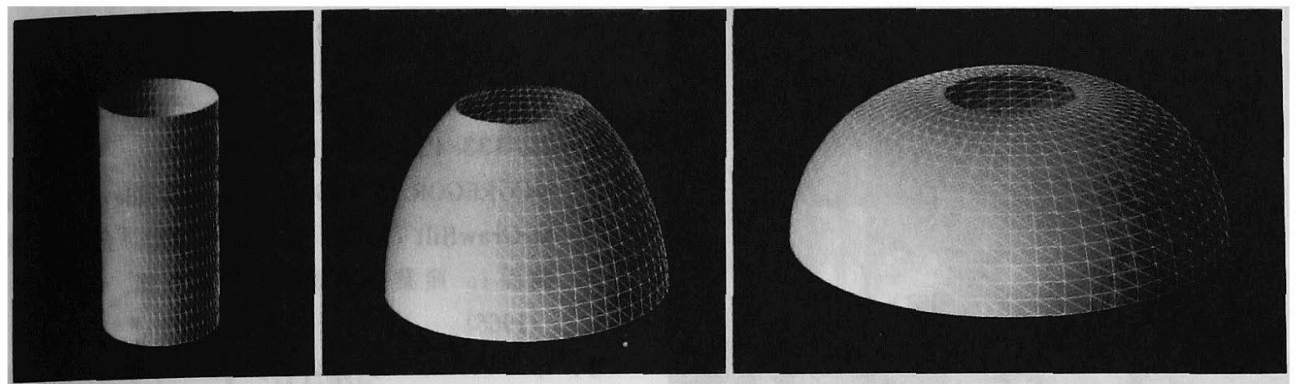

図 6 言葉で形を変える

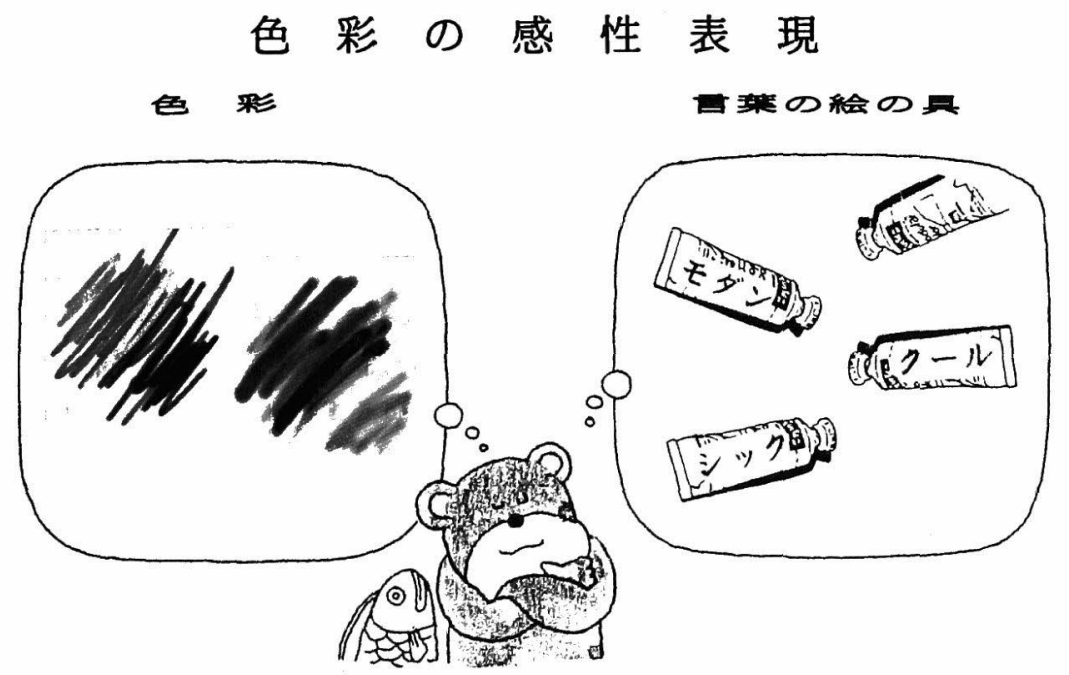

図7言葉で色を創る

が分かる。

\section{2 対铦型デザインの要素技術}

日常の言葉によって EOS とやり取りできれば，被服 デザインの設計に一般のユーザーが参加できる。「言葉 でデザインを」がEOSの重要なテーマである。

\subsection{1言菜で形を}

図 6 は，円筒と半球の基本図形から任意の割合で中間 の図形を合成する方法である ${ }^{7)}$ 。この方法は，各図形の 曲率ベクトルの重み付き線形合成和の例であるが，他に も EOSでは，ホップフィールドによる変わり格子柄の 生成法 ${ }^{8)}$ など様々な図形生成の方法を開発中である。何 れも図形生成関数と言語との簡単な関係から, 言葉でユ ーザーが欲している図形の生成が可能である。

\subsection{2吾荒で色やテクスチャーを}

色彩設計は，一般のユーザーにとっては難しい問題で ある。图7に示すように日常の言葉によって様々な色彩 設計ができたら被服デザインも非常に楽しいものになる
だろう。階層形ニューラルネットワークを用いた言語に よる色彩設計システム ${ }^{9)}$ は, 一度ユーザーに合わせて言 語と色彩の学習をさせておくと, 複数の言語の入力によ り各言語のイメージからくる色彩を合成した色を表現す ることができ, 言語で色彩のクリエイションが可能であ る。

また，画素の強度分布の分散を変えることで，テクス チャー表現を変化させることができる。この場合のテク スチャーの変化は, 布の暖かさの表現と関係しているの で, 結局分散を変えることによって暖かさの表現がコン トロールできる ${ }^{10)}$ 。

\subsection{3 言葉で体の姿勢を变える}

体の姿勢によって被服圧などは大きく変化する。どの 様な着心地の被服を作るかをシミュレーションするため には，言葉で人体モデルを変形させたい。ファジィ理論 と言語とを用いて人体モデルに各種の動作をさせた例を 図 8 に示す ${ }^{11) 。 ~}$ 


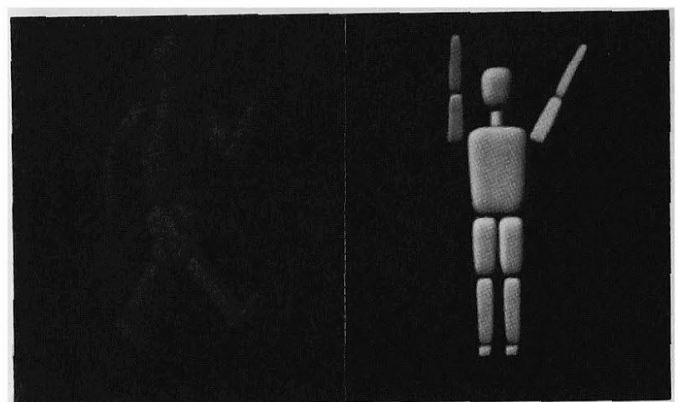

図 8 言葉で人体モデルの姿勢を変える

\section{5. 今後の課題}

前節では，言葉による被服デザインの要素技術 ${ }^{12)} の$ 例を見てきたが，他にもハードウェアからソフトウエア まで様々な技術を開発する必要がある。例えば, ソフト マテリアルハンドリングは自動縫製ロボットの実現にと って基本的な問題である。また, 被服素材から感性まで 広い分野を統合した複雑なユーザーモデルの構築はデー 夕ベースや並列処理の問題とも絡んだスケールの大きな 問題である。同時にユーザーモデルというパーソナルデ 一タベースが外部に漏れることなく, 安全に運用される ような仕組みも考えなければならない。

また, 今後重要な課題として老人や病人の衣料の問題 がある。今まで弱者とされた人々にこそ, 各人の状態に 合わせた適切な衣料を作りたい。

以上は, どれも㵶維科学技術の最先端の問題である が, 同時に情報科学技術や他の学問分野にとっても新し くて面白い問題である。ファッションテクノロジーに は，今後見る夢の技術が山のように隠されている。他の 分野と繊維科学技術との融合が 21 世紀のファッションテ クノロジーを創造し, 生き生きとした心豊かな人々が宇 宙船地球号というオムニバスに仲良く乗り合うようにし たいものだ。

\section{引用文献}

1. MASLOW, A,H., Higher and lower needs., J. of Psychol., 25, 433-436 (1948)

2. MCGREGOR, D., 1960., The human side of enterprise. McGrawHill (1960)，高橋達男（訳）「企業の人間的 側面」, 産業能率短期大学出版部, p p , 42-45 (1966)

3.トマス・カーライル「サータ・リザータス」春秋 社 柳田泉（訳）(1940)

4. 坂口明男, 佐々木和也, 篠原和夫, 清水義雄, 近田 淳雄, 清水裕子, 染谷久雄, 䋐維学会, 第12回織維 連合研究発表会講演要旨集p187 (1990)

5 . 清水義雄, 佐々木和也, 坂口明男, 篠原和夫, 近田 淳雄, 清水裕子, 織維学会, SEN-I GAKKAI PRE. PRINTS S-113 (1990)

6. 佐々木和也, 坂口明男, 清水義雄, 近田淳雄, 峨䧽 学会, SEN-I GAKKAI PREPRINTS S-160, 1991; 緎学誌投稿中

7. Y. Shimizu, J. Wang, A. Konda, K. Terada, N. Kumota and K. Kanda, SEN-I GAKKAISHI, 45 5, 199-205 (1989)

8. 前田昭一, 唐沢朋久, 清水義雄, 近田淳雄, 桟学誌 投稿中

9. Yoshio SHIMIZU, Akinori FUJIW ARA, Takao FURU. KAWA, kazuya SASAKI, Atsuo KONDA, 棧学誌 48, 5, 199-205 (1992)

10. 手島邦臣, 唐沢朋久, 清水義雄, 近田淳雄, 䄉維学 会, SEN-I GAKKAI PREPRINTS F-88 (1991); 阵学 誌投稿中

11. 汪進, 清水義雄, 近田淳雄, 第 7 回北信越ファジィ 研究会 (1991) ；繊学誌投稿中

12. 篠原昭, 白井汪芳, 近田淳雄共編, 「ニューファイ バーサイエンス」, 培風館, pp,97-114 (1990)

(平成 4 年 4 月20日受理) 